\section{Effect of Different Irrigating Solutions and Photo-Activated Therapy for In Vivo Root Canal Treatment}

Fernanda Ullmann López ${ }^{1}$, Patrícia Maria Poli Kopper ${ }^{2}$, Alvaro Della Bona ${ }^{3}$, Liviu Steier ${ }^{4}$, José Antônio Poli de Figueiredo ${ }^{1}$, Fabiana Vieira Vier-Pelisser ${ }^{1}$

\author{
'Post-Graduate Program in Dentistry, \\ Dental School, PUCRS - Pontifícia \\ Universidade Católica do Rio Grande \\ do Sul, Porto Alegre, RS, Brazil \\ ${ }^{2}$ Post-Graduate Program in \\ Dentistry, Dental School, UFRGS - \\ Universidade Federal do Rio Grande \\ do Sul, Porto Alegre, RS, Brazil \\ ${ }^{3}$ Post-Graduate Program in Dentistry, \\ Dental School, UPF - Universidade de \\ Passo Fundo, Passo Fundo, RS, Brazil \\ ${ }^{4}$ Graduate Program in Dentistry, \\ Warwick Medical School, University \\ of Warwick, Coventry, UK
}

Correspondence: Dra. Fernanda Ullmann López, Avenida lpiranga, 6681, 90619-900 Porto Alegre, RS, Brasil.Tel: +55-51-3026-7311. e-mail: fernanda.ullmann.lopez@gmail.com

Key Words: photo-activated therapy, periapical periodontitis, light microscopy, superoxidized waters.

\section{Introduction}

The persistence of infection within the apical third of treated root canals is the main factor responsible for endodontic failures. The complexity of the internal anatomy of root canals prevents complete mechanical removal of the microorganisms by current instrumentation techniques (1). In this context, irrigation plays an important role in disinfecting the regions that cannot be assessed by endodontic instruments. Sodium hypochlorite $(\mathrm{NaOCl})$ is the most frequently used irrigating solution due to its capability of dissolving organic tissues (2) and its broad antimicrobial spectrum (3). However, because of its cytotoxicity (4), dentin strength weakening (5) and corrosion of NiTi-files causing early fractures (6), alternative disinfecting protocols have been investigated, including chemicals and photo-activated disinfection (PAD) therapy.

Super-oxidized waters (SOWs) were first used in dental and medical unit disinfection due to their antimicrobial effect, capability to remove biofilm and low toxicity (7). Sterilox's Aquatine Alpha Electrolyte is a hypochlorous acid solution ( $\mathrm{pH}$ between 5.0 - 6.5) and has been suggested as an alternative irrigating solution for $\mathrm{NaOCl}$ as it showed efficient cleaning of root canal walls (8). 200 ppm Sterilox was tested in vitro against Enterococcus faecalis and showed bacterial load decrease, but it was less effective than $\mathrm{NaOCl}$ (9). However, there is no evaluation of its efficacy in vivo as a root canal irrigating solution. In addition, the antimicrobial effect and biocompatibility of concentrations greater than $200 \mathrm{ppm}$ have not been investigated. This is a very important issue since the antimicrobial activity of SOW depends on highly reactive non-specific oxidants that are almost extinguished by the high levels of organic load present within the biofilm structure, so a sufficient concentration and exposure time would be required (10).

Another disinfecting system, the PAD, has shown promising results when tested in vitro $(11,12)$ and in vivo (13). As an adjunct to conventional root canal therapy, it aims to maximize the antimicrobial effect, reducing the treatment time and increasing the success rates. PAD has proved to be effective against endodontic microorganisms, even when organized in biofilms (14). Besides, it acts in a selective way. The photosensitizer stains the bacterial cells in soft and hard tissues and the photo-activated cells release molecular oxygen causing disruption of the bacterial cell wall. Both photosensitizer and oxygen released during bacterial cell death do not exhibit toxicity to the patient (15).

Although $\mathrm{NaOCl}$ is the irrigating solution of choice, the effective removal of biofilm requires a direct contact with the microorganisms, a greater volume of the solution, high concentrations and contact time that requires a prolonged treatment time (16). All these factors imply in increased 
toxicity and adverse side effects. Therefore, the present study evaluated histologically the effect of irrigation with $400 \mathrm{ppm}$ Sterilox, 2\% and 5\% $\mathrm{NaOCl}$, with and without $P A D$, in a single visit root canal treatment of dog's teeth with apical periodontitis. The hypothesis tested was that Sterilox, when used in a higher concentration and in clinical conditions, could present histological findings similar to $\mathrm{NaOCl}$ and better than saline solution, and that PAD used after chemo-mechanical preparation could provide lower scores for apical inflammation than when it was not used.

\section{Material and Methods}

This study was approved by the local Ethical Committee for Animal Experiments (approval protocol CEUA 009/2011). A total of 134 root canals from maxillary and mandibular premolars of 10 mongrel dogs (aged between 12-18 months) were used. For each experimental phase, the animals were anesthetized intramuscularly (IM) using $1 \mathrm{mg} / \mathrm{kg} \quad 0.2 \%$ acepromazine (Eurofarma, São Paulo, SP, Brazil) and then intravenously (IV) using $8 \mathrm{mg} / \mathrm{kg} 1 \%$ propofol (Eurofarma) and 3 to $4 \mu \mathrm{g} / \mathrm{kg}$ fentanyl (Eurofarma). The dose was supplemented IV using $4 \mathrm{mg} / \mathrm{kg}$ of propofol and $3 \mu \mathrm{g} / \mathrm{kg}$ of fentanyl every $30 \mathrm{~min}$. After the procedures, the animals received IM $2 \mathrm{mg} / \mathrm{kg}$ of tramadol hydrochloride (Eurofarma) every $12 \mathrm{~h}$ for analgesia.

Dental procedures were carried out by a specialist in endodontics. Cavity accesses were made in the mesial and distal fossae of the occlusal surface of right and left maxillary and mandibular premolars. The working length (WL) was established at $1 \mathrm{~mm}$ short of the radiographic apex using a \#20 K-file (Dentsply Maillefer, Ballaigues, Switzerland). The pulp was removed and the apical foramen was disrupted and enlarged up to \#30 K-file at the radiographic apex. Root canals were left open for 2 weeks and then sealed using zinc oxide/eugenol cement (IRM; Dentsply, Petropolis, RJ, Brazil) (17).

After 60 days, the dogs were randomly divided in two groups $(n=5)$ : with or without PAD. Then the canals were divided into four subgroups, according to irrigating solution: 400 ppm Sterilox (SX) (Optident Dental, Ilkley, WY, United Kingdom), 2\% (SH2) and 5\% (SH5) NaOCl (PanVel, Porto Alegre, RS, Brazil) and saline solution (SS).

The root canals were prepared with K-files at the WL up to \#55 size. At every instrument change, canals were flushed with $2 \mathrm{~mL}$ of an irrigating solution using a disposable $10-\mathrm{mL}$ syringe (BD, Elkhart, IN, USA) and a 30-gauge needle (Ultradent, South Jordan, UT, USA) at 2 $\mathrm{mm}$ short from WL. After preparation, canals were flushed with $2 \mathrm{~mL}$ of 17\% EDTA (Biodinamica, lbiporã, PR, Brazil) left for $3 \mathrm{~min}$ in the canal with manual agitation using a \#50 K-file followed by a flush of $2 \mathrm{~mL} \mathrm{SS}$. The canals were dried with sterile \#55 paper points (Dentsply Maillefer). In the PAD group, the canals were filled with toluidine blue solution $(12,7 \mathrm{mg} / \mathrm{mL}, \mathrm{pH}$ ) using a $10-\mathrm{mL}$ disposable syringe and a 30-gauge needle and agitated for 60 s using a \#50 K-file inserted up to the WL. The excess dye was removed and PAD-Plus (Dexcel Dental, Daventry, NN, UK) was used in the parameters of $635 \mathrm{~nm}, 100 \mathrm{~mW}$ and $15 \mathrm{~J}$, as recommended by the manufacturer. The flexible optical fiber was introduced up to $2 \mathrm{~mm}$ short from the WL and withdrawn to coronal third. This movement was repeated during $120 \mathrm{~s}$. After use of PAD, canals were washed with 2 $\mathrm{mL}$ of SS and dried with paper points. All canals were filled according to Tagger's technique using gutta-percha points (Dentsply Maillefer) and AH Plus sealer (Dentsply, De Trey, Konstanz, Germany). The access cavities were sealed with silver amalgam (DFL).

Four months after endodontic treatment, the animals were euthanized using an anesthetic overdose followed by a 10\% formalin buffer solution perfusion. The jaws were separated, dissected and kept immersed in 10\% formalin buffer solution.

The jaws were sectioned to obtain individual roots and demineralized in 5\% nitric acid. After embedding in paraffin, areas showing apical foramen disruption and periapical region were serially sectioned in 5 - $\mu$ m-thick slices and stained with hematoxylin and eosin. The sections were analyzed ( $40 \times$ to $400 \times$ magnification) by a calibrated (Kappa $=0.889 \pm 0.061 ; p<0.05)$ and blinded evaluator, under light microscopy (Nikon Eclipse E200; Nikon Corp., Tokyo, Japan) and classified according to the ascending order of inflammation severity (18) (Fig. 1).

Data were statistically analyzed by nonparametric Kruskal-Wallis and Mann-Whitney tests. The significance level was set at $\alpha=0.05$.

\section{Results}

Considering the irrigating solutions, specimens from groups SH5, SH2 and SX without PAD were statistically different from SS group $(p=0.02)$, which showed the greatest score for periapical inflammation (Table 1). No significant difference was found among groups where PAD was used. Therefore, the ç and scores of apical inflammation for SX specimens were not statistically different from the ones found for SH5 and SH2 specimens, which also applies for SX/PAD (Figs. 1A and 1B) specimens compared to SH5/PAD (Figs. 1C and 1D) and SH2/PAD specimens (Table 1). The histopathological evaluation of periapical region of SS specimens showed great microcavities of acute inflammatory infiltrate and areas of resorption in the apical cementum (Figs. 1E-1H).

When the effect of PAD was evaluated for each irrigating solution (Table 1), there was no significant difference in the scores of inflammation. 

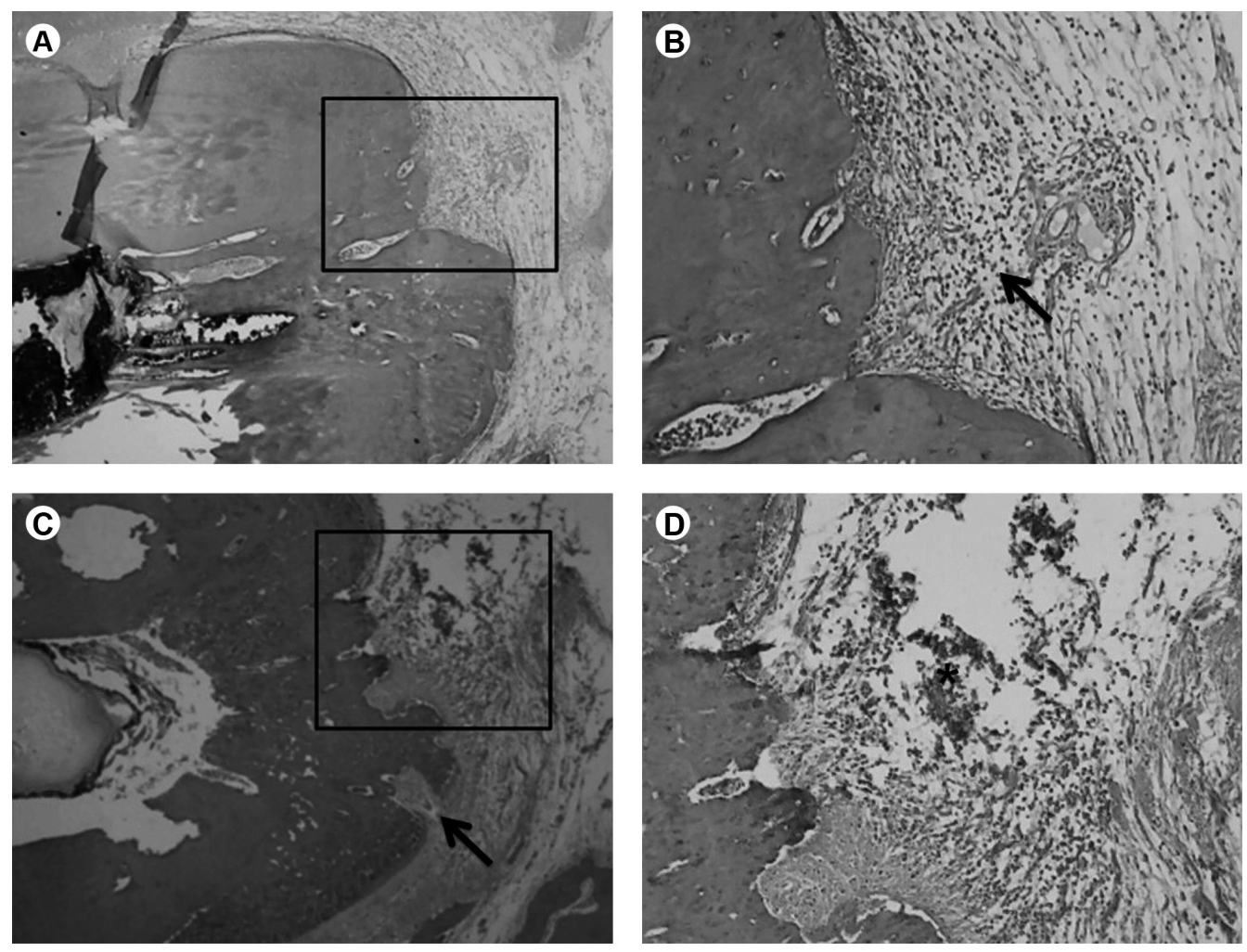

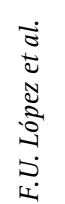
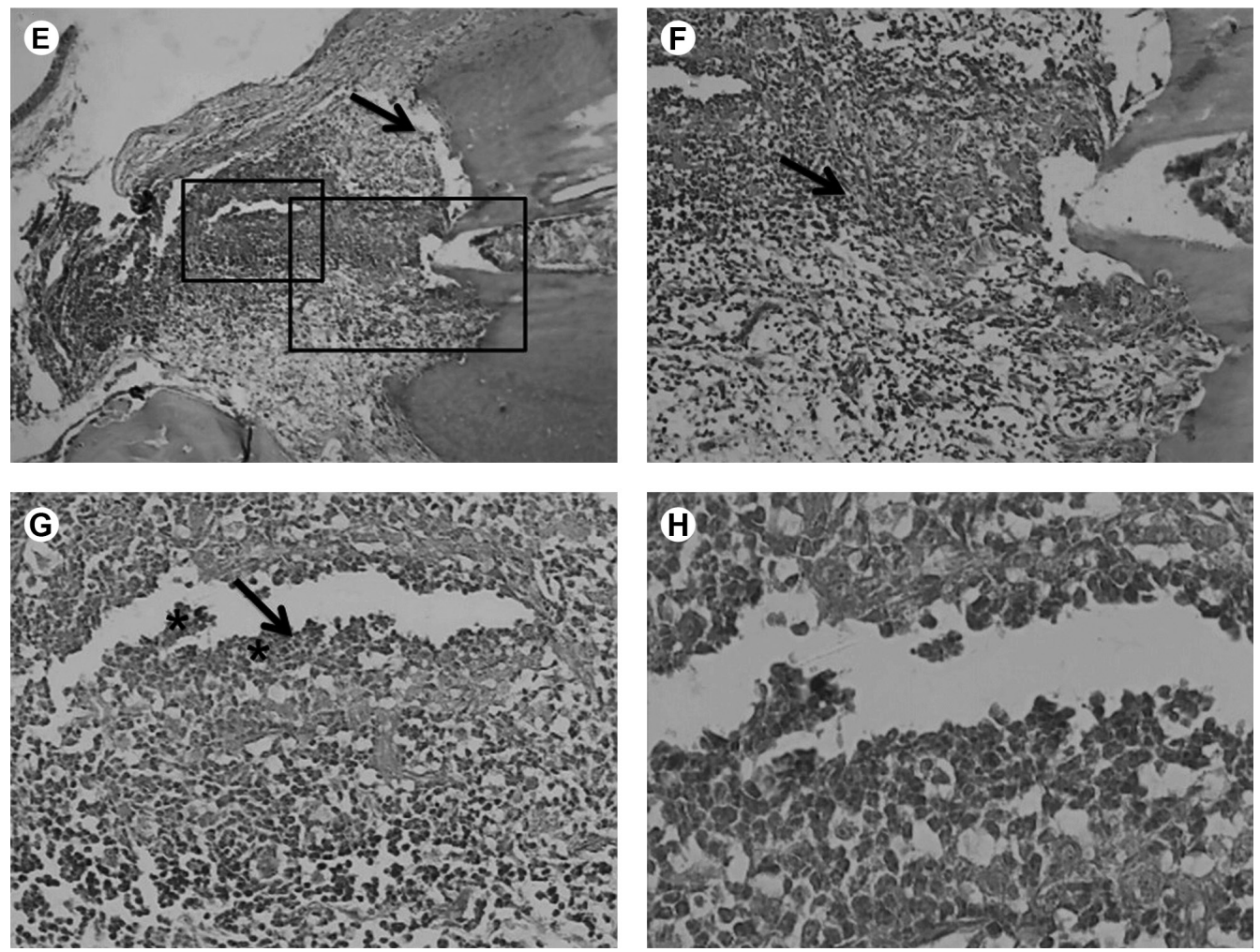

Figure 1. Composite figure showing the histopathological findings. A and B: images illustrating a score 1 from SX/PAD specimen (hematoxylin-eosin). $A$ is an image (40x) of the periapical region showing mild and sparse mononuclear cells. Close up image of the area within the square (image $A$ ) is shown in image B (100x). Arrows indicate mononuclear cells. Images C and D illustrate a score 2 from SH5/PAD specimen (hematoxylin-eosin). C: Image $(40 x)$ of the periapical region showing moderate infiltrate of mononuclear cells. Arrow indicates one of the resorption areas. D: Higher magnification $(100 \times)$ of the area within the square in image C. Asterisk indicates area of moderate infiltrate of mononuclear cells. Images E, F, G and H illustrate a score 3 from SS specimen (hematoxylin-eosin). (E) lmage (40x) of the periapical region showing severe inflammatory reaction. Black arrow indicates a resorption area. F: Higher magnification (100x) of the area within the largest square in image E. Arrow indicates area of severe inflammatory infiltrate. G: Higher magnification $(200 x)$ of the area within the smallest square in image E. Black arrow indicates an area of abscess, associated to infiltrate of degenerated polymorphonuclear neutrophils (*). H: Close up (400x) of image G. 


\section{Discussion}

Endodontic therapy in a single visit is convenient for the patient and desirable to avoid re-colonization and re-infection of the root canal system by repeated appointments and inadequate coronal sealing. Thus, effective disinfecting protocols capable of achieving the treatment in as few visits as possible have been intensively studied for the last years $(13,19)$.

The qualitative analysis proposed in the present study was previously reported $(20,21)$. Considering the histological findings and the scores for apical inflammation

Table 1 Distribution of cases according to the histological scores: comparison among irrigating solutions and between each solution with and without PAD.

\begin{tabular}{|c|c|c|c|c|c|c|}
\hline \multirow{2}{*}{$\begin{array}{l}\text { Irrigating } \\
\text { Solutions }\end{array}$} & \multirow{2}{*}{$\begin{array}{l}\text { Histological } \\
\text { Scores }\end{array}$} & \multicolumn{2}{|c|}{ Without PAD } & \multicolumn{2}{|c|}{ With PAD } & \multirow{2}{*}{$\mathrm{P}^{*}$} \\
\hline & & $n$ & $\%$ & $n$ & $\%$ & \\
\hline \multirow[t]{4}{*}{ SH5 } & Score 0 & - & - & - & - & 0.209 \\
\hline & Score 1 & 7 & 33.34 & 9 & 52.95 & \\
\hline & Score 2 & 12 & 57.14 & 8 & 47.05 & \\
\hline & Score 3 & 2 & 9.52 & - & - & \\
\hline Total & & $21^{\mathrm{Aa}}$ & 100.00 & $17^{\text {Аа }}$ & 100.00 & \\
\hline \multirow[t]{4}{*}{$\mathrm{SH} 2$} & Score 0 & 1 & 6.67 & 1 & 4.78 & 0.899 \\
\hline & Score 1 & 4 & 26.67 & 4 & 19.04 & \\
\hline & Score 2 & 7 & 46.66 & 15 & 71.42 & \\
\hline & Score 3 & 3 & 20.00 & 1 & 4.76 & \\
\hline Total & & $15^{\text {Аa }}$ & 100.00 & $21^{\text {Аa }}$ & 100.00 & \\
\hline \multirow[t]{4}{*}{ SX } & Score 0 & 2 & 11.12 & - & - & 0.828 \\
\hline & Score 1 & 6 & 33.33 & 7 & 35.00 & \\
\hline & Score 2 & 6 & 33.33 & 11 & 55.00 & \\
\hline & Score 3 & 4 & 22.22 & 2 & 10.00 & \\
\hline Total & & $18^{\mathrm{Aa}}$ & 100.00 & $20^{\text {Aa }}$ & 100.00 & \\
\hline \multirow[t]{4}{*}{ SS } & Score 0 & - & - & - & - & 0.107 \\
\hline & Score 1 & - & - & 2 & 16.67 & \\
\hline & Score 2 & 4 & 40.00 & 7 & 58.33 & \\
\hline & Score 3 & 6 & 60.00 & 3 & 25.00 & \\
\hline Total & & $10^{\mathrm{Ba}}$ & 100.00 & $12^{\text {Аа }}$ & 100.00 & \\
\hline
\end{tabular}

Different uppercase letters indicate statistically significant difference within columns (among the irrigating solutions) $(p<0.05)$. Same lowercase letters indicate absence of statistically significant difference within rows (for each solution with and without PAD) ( $p>0.05)$. of this study, all canal irrigating solutions $(2 \% \mathrm{NaOCl}, 5 \%$ $\mathrm{NaOCl}$ and $400 \mathrm{ppm}$ Sterilox) were more effective than SS. Similar results were produced when PAD therapy was added to the irrigating solutions protocols. Thus, 400 ppm Sterilox may be considered an alternative to $\mathrm{NaOCl}$ in root canal treatment, since Sterilox was as effective as $2 \%$ and $5 \% \mathrm{NaOCl}$ solutions, which confirms the first study hypothesis.

Lately many studies have shown that the disinfecting actions of super-oxidized waters are heavily reduced by organic contamination $(9,15,22)$. The high levels of organic load present in the root canals, as in the biofilm structure, particularly in the extracellular polymeric matrix, competitively quenched the reactive oxidants of superoxidized waters that are responsible for its antimicrobial activity (22). Thus, the usual concentration of Sterilox was increased in the present research, trying to overcome this disadvantage. A sufficient concentration and exposure time would be required to reach cells deeper within the biofilm architecture (22).

Most in vitro studies (9) about the antimicrobial effect of Sterilox neither have the contact time nor simulate the clinical conditions where the irrigating solution is used. When an irrigating solution is evaluated during mechanical preparation, its antimicrobial effect may be improved. The instrumentation helps to introduce the solution into the apical part of root canal, to remove organic and inorganic contents and to disrupt the structures of biofilms allowing a better action of the irrigating solution. It seems that besides the greater concentration of Sterilox used in this study, the use in the clinical conditions has improved its effect. The results also suggest that the effect of an irrigating solution may be different if it is tested during the chemomechanical preparation or just by flushing or by contact. Rossi-Fedele et al. (9) evaluated the antimicrobial effect of irrigation using $200 \mathrm{ppm}$ Sterilox and 5\% $\mathrm{NaOCl}$ isolated without mechanical preparation of root canals of bovine teeth contaminated with Enterococcus faecalis. Only the $5 \% \mathrm{NaOCl}$ solution showed effectiveness. The authors suggested that the super-oxidized water irrigation may have clinically relevant results in reduced bacterial load, e.g. chemomechanical preparation. This same study also reported on the lower level of toxicity of Sterilox, when compared to $\mathrm{NaOCl}$. This is in agreement with Shetty et al. (23) who mentioned that Sterilox is non-toxic to biological tissues and nonirritant to skin, since its $\mathrm{pH}$ ranges from 5 to 6.5 .

The effect of PAD immediately after root canal chemomechanical preparation, as a supplement therapy, as proposed for endodontics (24), was evaluated in the present study. According to Souza et al. (19), instrumentation and irrigation modify the environment of root canal and 
may disrupt biofilms structures, making the bacterial community more susceptible to the action of PAD. In addition, the effect of PAD is expected in the areas where the instruments and irrigating solutions do not penetrate, complementing the disinfection of the residual microorganisms.

Considering the results of the present study, PAD did not produce significant differences in the scores for apical inflammation for the specimens irrigated with $\mathrm{NaOCl}$, Sterilox and SS. Yet the findings are in agreement with the in vitro study of Souza et al. (19) disagree with the in vivo study of Silva et al. (13). The authors (19) suggested that the results could be explained because the effect of PAD was probably restricted to the root canal areas already reached by the irrigating solutions. Another study investigated the antimicrobial effect of PAD in vivo (13). The authors (13) evaluated the apical response to PAD alone and with the chemomechanical debridement in root canals of dogs' teeth with AP. They found no inflammatory cells and moderate neoangiogenesis when PAD was used after chemomechanical preparation of the root canal. The used methodology (13) was similar to the present study, except for the mechanical preparation, which was performed up $\dot{\sigma}$ to \#55 size. Maybe the greater apical preparation achieved in the present work is responsible for the absence of significant differences with the use of PAD therapy.

In addition, most of the previous studies that showed adequate root canal disinfection with the use of PAD alone $(12,25)$ or combined with chemomechanical debridement $(25,26)$ sampled the root canal content using paper points or aspiration. These methods are limited by sampling only planktonic bacteria, not taking into account the bacteria organized in biofilms and inside dentinal tubules.

Considering the PAD therapy, Egan et al. (27) showed that the light transmission through the tooth tissue at the operating wavelength appears to be good and attenuation in sound dentin is minimal with up to $3-\mathrm{mm}$ thick dentine slices. In addition, Bonsor et al. (28) have shown that the photosensitizer has good wettability properties. Perhaps, even after root canal instrumentation, the photosensitizer cannot penetrate completely into irregularities and dentinal tubules, leaving untouched biofilms within the canal walls. As the action of PAD is limited to the areas reached by the dye, its effect is limited. Therefore, a PAD protocol for effective antibacterial supplement to chemomechanical therapy remains to be established.

Within the experimental conditions and the resulting data, this study suggests that PAD does not have additional effect in a single visit root canal treatment of teeth with pulp necrosis and apical periodontitis. Nevertheless, 400 ppm Sterilox showed same effectiveness as the $\mathrm{NaOCl}$ irrigating solutions and, therefore, it can be considered as an alternative to replace $\mathrm{NaOCl}$ irrigating solution.

\section{Resumo}

Este estudo realizou uma avaliação histológica do efeito das soluções irrigadoras Sterilox 400 ppm e hipoclorito de sódio $(\mathrm{NaOCl})$ a $2 \%$ e $5 \%$, com e sem a terapia fotodinâmica (PAD), na endodontia em sessão única de dentes de cães associados a lesões periapicais (APs). Dez cães foram divididos de forma randomizada em dois grupos $(n=5)$ : com e sem PAD, e os canais radiculares em quatro subgrupos, de acordo com a solução irrigadora utilizada: SX (Sterilox 400 ppm), SH2 ( $\mathrm{NaOCl} 2 \%), \mathrm{SH} 5(\mathrm{NaOCl}$ $5 \%$ ) e SS (solução salina) como controle positivo. Cento e trinta e quatro canais foram abertos e deixados expostos ao meio oral por 14 dias e depois selados por 60 dias para a indução de APs. Na sequência, os canais foram tratados de acordo com cada protocolo de desinfecção proposto e obturados na mesma sessão. Após 120 dias, os cães foram mortos e os eventos inflamatórios periapicais foram avaliados em microscopia óptica. 0s dados qualitativos foram analisados estatisticamente pelos testes KruskalWallis e Mann-Whitney $(\alpha=0,05)$. A PAD, quando empregada após o preparo químico-mecânico, não promoveu diferenças significativas nos escores para inflamação apical $(p>0,05)$. As soluções irrigadoras SX, SH2 e SH5 sem PAD apresentaram diferenças estatísticas do grupo $S S(p<0,05)$ que apresentou os maiores escores para inflamação apical. A PAD não apresentou efeito adicional na endodontia em sessão única dos canais com necrose pulpar associados a lesão apical e a solução irrigadora Sterilox 400 ppm pode ser considerada uma alternativa ao $\mathrm{NaOCl}$ na terapia endodôntica.

\section{References}

1. Nair PNR, Henry S, Cano V, Vera J. Microbial status of apical root canal system of human mandibular first molars with primary apical periodontitis after 'one-visit' endodontic treatment. Oral Surg Oral Med Oral Pathol Oral Radiol Endod 2005;99:231-252.

2. Naenni N, Thoma K, Zehnder M. Soft tissue dissolution capacity of currently used and potential endodontic irrigants. J Endod 2004;30:785787.

3. Siqueira J, Batista M, Fraga R, de Uzeda M. Antibacterial effects of endodontic irrigants on black-pigmented gram-negative anaerobes and facultative bacteria. J Endod 1998;24:414-416.

4. Gatot A, Arbelle J, Leiberman A, Yanai-Inbar I. Effects of sodium hypochlorite on soft tissues after its inadvertent injection beyond the root apex. J Endod 1991;17:573-574.

5. White JD, Lacefield WR, Chavers LS, Eleazer PD. The effect of three commonly used endodontic materials on the strength and hardness of root dentin. J Endod 2002;28:828-830.

6. Berutti E, Angelini E, Rigolone M, Migliaretti G, Pasqualini D. Influence of sodium hypochloride on fracture properties and corrosion of ProTaper Rotary instruments. Int Endod J 2006;39:693-699.

7. Martin MV, Gallagher MA. An investigation of the efficacy of superoxidized (Optident/Sterilox) water for the disinfection of dental unit water lines. Br Dent J. 2005;198:353-354.

8. Solovyeva AM, Dummer PM. Cleaning effectiveness of root canal irrigation with electrochemically activated anolyte and catholyte solutions; a pilot study. Int Endod J 2000;33:494-504.

9. Rossi-Fedele G, Figueiredo JAP, Steier L, Canullo L, Steier G, Roberts AP. Evaluation of the antimicrobial effect of super-oxidized water (Sterilox ${ }^{\circledR}$ ) and sodium hypochlorite against Enterococcus faecalis in a bovine root canal model. J Appl Oral Sci 2010;18:498-502.

10. Rossi-Fedele G, Steier L, Dogramaci EJ, Canullo L, Steier G, de Figueiredo JA. Bovine pulp tissue dissolution ability of HealOzone ${ }^{\circledR}$, Aquatine Alpha Electrolyte ${ }^{\circledR}$ and sodium hypochlorite. Aust Endod J 2013;39:57-61.

11. Cheng $X$, Guan $S$, Lu H, Zhao C, Chen $X$, Li N, et al.. Evaluation of the bactericidal effect of Nd:YAG, Er:YAG, Er,Cr:YSGG laser radiation, and antimicrobial photodynamic therapy (aPDT) in experimentally infected root canals. Lasers Surg Med 2012;44:824-831.

12. Bago I, Plecko V, Panduric DG, Schauperl Z, Baraba A, Anic I. Antimicrobial efficacy of a high-power diode laser, photo-activated disinfection, conventional and sonic activated irrigation during root 
canal treatment. Int Endod J 2013:46:339-347.

13. Silva $L A B$, Novaes $A B$, Oliveira RR, Nelson-Filho $P$, Santamaria $M$, Silva RAB. Antimicrobial photodynamic therapy for the treatment of teeth with apical periodontitis: a histopathological evaluation. J Endod 2012;38:360-366.

14. Stojicic S, Amorim H, Shen Y, Haapasalo M. Ex vivo killing of Enterococcus faecalis and mixed plaque bacteria in planktonic and biofilm culture by modified photoactivated disinfection. Int Endod J 2013;46:649-659.

15. Soukos NS, Wilson M, Burns T, Speight PM. Photodynamic effects of toluidine blue on human oral keratinocytes and fibroblasts and Streptococcus sanguis evaluated in vitro. Lasers Surg Med 1996;18:253259.

16. Haapasalo M, Shen Y, Qian W, Gao Y. Irrigation in endodontics. Dent Clin North Am 2010;54:291-312.

17. Tanomaru JMG, Leonardo M, Tanomaru Filho M, Bonetti Filho I, Silva LAB. Effect of different irrigation solutions and calcium hydroxide on bacterial LPS. Int Endod J 2003;36:733-739.

18. Moure SP, de Vargas KF, Borghetti RL, Salum FG, Cherubini K, da Silva VD, et al.. Clinical and pathological characteristics of polymethylmethacrylate and hyaluronic acid in the rat tongue. Int J Oral Maxillofac Surg 2012;41:1296-1303.

19. Souza LC, Brito PRR, Oliveira JCM, Alves FRF, Moreira EJL, Sampaio-Filho $H R$, et al.. Photodynamic therapy with two different photosensitizers as a supplement to instrumentation/irrigation procedures in promoting intracanal reduction of Enterococcus faecalis. J Endod 2010;36:292-296.

20. Gomes MS, Barletta FB, Della Bona A, Vanni JR, da Pereira C, Figueiredo JAP. Microbial leakage and apical inflammatory response in dog's teeth after root canal filling with diferent sealers, post space preparation and exposure to the oral environment. J Appl Oral Sci 2007;15:429-436.

21. Borghetti RL, Vargas KF, Moure SP, Salum FG, Figueiredo MA. Clinical and histologic evaluation of effects of hyaluronic acid in the rat tongue. Oral Surg Oral Med Oral Pathol Oral Radiol Endod 2012;113:488-494.

22. Thorn RMS, Lee SWH, Robinson GM, Greenman J, Reynolds DM. Electrochemically activated solutions: evidence for antimicrobial efficacy and applications in healthcare environments. Eur J Clin Microbiol Infect Dis 2012;31:641-653.

23. Shetty N, Srinivasan S, Holton J, Ridgway GL. Evaluation of microbicidal activity of a new disinfectant: Sterilox ${ }^{\circledR} 2500$ against Clostridium difficile spores, Helicobacter pylori, vancomycin resistant Enterococcus species, Candida albicans and several Mycobacterium species. J Hosp Infect 1999;41:101-105.

24. Rios A, He J, Glickman GN, Spears R, Schneiderman ED, Honeyman AL. Evaluation of photodynamic therapy using a light-emitting diode lamp against Enterococcus faecalis in extracted human teeth. J Endod 2011;37:856-859.

25. Garcez AS, Nunez SC, Hamblin MR, Ribeiro MS. Antimicrobial effects of photodynamic therapy on patients with necrotic pulps and periapical lesion. J Endod 2008;34:138-142.

26. Ng R, Singh F, Papamanou DA, Song $X$, Patel C, Holewa $C$, et al.. Endodontic photodynamic therapy ex vivo. J Endod 2011;37:217-222.

27. Egan J, Collis J, Pearson G J, Williams J. Transmission of $636 \mathrm{~nm}$ diode laser light through dentine. Colorado, USA: Transaction of SPIE, 2000.

28. Bonsor SJ, Nichol R, Reid TM, Pearson GJ. An alternative regimen for root canal disinfection. Br Dent J 2006;201:101-105.

Received July 3, 2014 Accepted January 13, 2015 